\title{
WANPRESTASI PEMBAYARAN KLAIM ASURANSI JIWA AKIBAT KELALAIAN PENYERAHAN BERKAS OLEH MITRA PENANGGUNG SEBAGAI KOLEKTOR PENGAJUAN KLAIM (Studi Kasus Sertifikat Asuransi Polis Nomor 15.001673)
}

\author{
Inawati Santini \\ Fakultas Ilmu Hukum, Universitas Pamulang \\ Email: miss.inawati@gmail.com
}

\begin{abstract}
At this time many banks are incentive to lure consumer credit to consumers. In general, consumer loan interest rate is higher than productive credit, even there is a fixed rate. It seems that the fixed rate makes it easy to organize family finances, paying only monthly installments of the same amount, but if carefully calculated, the interest is much higher. Consumer Loan Protection with Insurance Policy Certificate 15.001673 is a life insurance product that guarantees repayment of the remaining amount of Loans and / or monthly loan installment of the Customer as Participant (Insured) to the Policyholder in case the Participant (the Insured) has a death risk or total temporary disability / Or total permanent disability. Although it is clear about the rights and obligations in the insurance agreement but the reality is very different because it turns out the insurer does not fulfill its obligations in the event of claim submission from the insured. Rejection of insurance claims may be made by the insurer under the pretext of submitting the file beyond the specified time limit. Issues to be studied further is how validation of denial of life insurance claim made by Jasindo in accordance with the insurance policy and existing legislation and whether Partner Error is can be classified as Wanprestasi payment of Insurance Claim for late in submission of policy file No: 15.001673. In conducting research, this research is normative law research that is research having object of study about rule or rule. The objective is to determine the validity of the refusal of insurance claims made by Jasindo in accordance with the existing insurance policies and regulations and to find out the Default Payment of Insurance Claims due to Delayed Submission by Marketing Party as Collector Submission of Claim on Insurance Certificate Number 15.001673.
\end{abstract}

Keywords: Asuransi, Wanprestasi, Pembayaran Klaim

\section{PENDAHULUAN}

Manusia pada hakikatnya akan selalu melewati apa yang dinamakan dengan siklus kehidupan. Secara umum siklus tersebut dimulai dari lahir, balita, anak-anak, remaja, dewasa, berkeluarga, lanjut usia dan yang terakhir adalah meninggal dunia. Seseorang akan merasa bahwa dirinya akan dalam keadaan sehat tanpa suatu penyakit apapun dan tidak memikirkan dikemudian hari ia akan jatuh sakit sehingga perlu menjalani perawatan dirumah sakit.

Kemungkinan meninggal dunia juga bisa terjadi ketika orang tersebut mengalami penyakit yang parah. Seseorang akan sadar ketika ia sudah dalam keadaan sakit dan merasa berat perihal biaya perawatan yang ia tanggung. Seseorang itu akan sadar pula 
ketika kepala keluarga yang memberi nafkah meninggal dunia, sehingga ia akan merasa sulit memenuhi kebutuhan sehari-harinya. Jadi setiap manusia akan menghadapi kemungkinan kehilangan nyawa karena berbagai sebab seperti terjangkit suatu penyakit atau karena kecelakaan yang mengakibatkan kematian.

Untuk membantu meringankan beban yang ditanggung keluarga yang ditinggalkan maka perlu adanya pihak lain yang dapat menanggung resiko tersebut. Pengalihan resiko ini bertujuan untuk memikul kerugian yang mana disebabkan karena suatu kejadian tertentu. Kerugian tersebut dapat dialihkan kepada pihak lain yang bergerak di bidang penerimaan resiko yaitu perusahaan asuransi.

Jadi perihal resiko dapat dialih atau dapat ditanggung oleh perusahaan asuransi tersebut dengan ketentuan dan juga syarat yang telah ditentukan sebelumnya. ${ }^{1}$

Ketentuan asuransi telah dijelaskan dalam Kitab Undang-Undang Hukum Dagang (selanjutnya disebut KUHD) dan juga Undang-Undang Nomor 40 Tahun 2014 tentang Perasuransian. Ketentuan asuransi dalam KUHD diatur pada Pasal 246 sedangkan dalam Undang-Undang Nomor 40 Tahun 2014 tentang Perasuransian diatur pada Pasal 1 Angka 1.

1 Dwi Tatak Subagiyo,Analisa Hukum Atas Penolakan Klaim Asuransi Kesehatan Prespektif, Refika Aditama, Bandung, 2012, hlm. 139
Ketentuan dari kedua pasal tersebut menjelaskan bahwa para pihak yang berkaitan dengan asuransi atau pertanggungan minimal terdapat dua yaitu penanggung dan tertanggung.Penanggung merupakan pihak yang berhak menerima pembayaran uang pertanggungan dan memberi penggantian apabila terjadi kerugian.Tertanggung merupakan pihak yang mengadakan perjanjian asuransi dengan membayar sejumlah uang dan menerima uang penggantian atas kerugian yang diderita. Tertanggung biasanya juga disebut dengan istilah yang berbeda seperti "pengambil asuransi" atau "pemegang polis", namun Pasal 304 Ayat (2) KUHD memakai istilah tertanggung. $^{2}$

Pada asuransi jiwa seorang yang telah berusia tua, maka nilai premi yang akan dibayarkan akan lebih besar dibandingkan dengan orang yang masih berusia muda. Seseorang yang berusia tua akan lebih beresiko mengalami kematian lebih cepat daripada seseorang yang masih berusia muda. ${ }^{3}$

Penanggung dan tertanggung mengikat kan diri dalam perjanjian asuransi harus sesuai dengan ketentuan peraturan perundangundangan yang berlaku yakni terdapat dalam Pasal 1338 Ayat (1) Kitab Undang - Undang Hukum Perdata (selanjutnya disebut KUHPer). Ketentuan ini menyatakan bahwa

2 Ali Rido, Hukum Dagang: Tentang AspekAspek Hukum Dalam Asuransi Udara, Asuransi Jiwa, dan Perkembangan Perseroan Terbatas, Remadja Karya, Bandung, 1986, hlm. 183-184

3 Abbas Salim, Dasar - Dasar Asuransi, Raja Grafindo Persada, Jakarta, 1995, hlm. 12 
ketika perjanjian telah disepakati kedua belah pihak, maka perjanjian tersebut akan berlaku sebagai undang-undang yang akan mengikat pihak-pihak didalamnya.

Pembuatan perjanjian asuransi juga harus memenuhi syarat-syarat perjanjian dimana ketentuan-ketentuan yang mengatur hal ini terdapat pada Pasal 1320 KUHPer mengenai syarat sahnya perjanjian.Perjanjian asuransi mempunyai unsur peristiwa yang tidak tentu, maka perjanjian asuransi dianggap sebagai perjanjian untung-untungan sebagaimana yang tercantum pada Pasal 1774 KUHPer.Perjanjian asuransi apabila diteliti dalam prakteknya, maka tidak dapat digolongkan dalam perjanjian untunguntungan walaupun digantungkan pada peristiwa yang tidak tentu. ${ }^{4}$

Hal ini didasarkan karena adanya alasan bahwa dalam perjanjian asuransi terdapat premi sebagai bentuk pembayaran pengalihan resiko yang seimbang dengan resiko yang ditanggung.

Selain itu juga terdapat unsur kepentingan sebagai syarat mutlak yang dimiliki tertanggung, serta jika terdapat permasalahan dalam jalannya perjanjian asuransi para pihak dapat menggugat dimuka pengadilan.

Proses pengalihan resiko dari tertanggung kepada penanggung tidak terjadi

${ }^{4}$ Abdulkadir Muhammad, Pokok-Pokok Hukum Pertanggungan, Citra Aditya Bakti, Bandung, 1990, hlm.31 begitu saja tanpa kewajiban apa-apa. Tertanggung yang telah sepakat akan mengadakan perjanjian asuransi dengan penanggung yang dalam hal ini adalah asuransi jiwa, mempunyai kewajiban membayar sejumlah uang kepada penanggung. Pembayaran uang tersebut digunakan untuk mengganti kerugian yang dialami tertanggung sedangkan penanggung wajib untuk menanggung besaran kerugian tersebut.Namun apabila kemudian peristiwa yang dimaksudkan dalam perjanjian tidak terjadi maka uang tersebut tetap menjadi milik pihak yang menanggung. ${ }^{5}$

Ketentuan-ketentuan yang dipakai oleh penanggung dalam mengikatkan dirinya dengan tertanggung diterjemahkan dalam polis. Polis ini nantinya akan menjadi tanda bukti adanya perjanjian asuransi.

Ketentuan-ketentuan tentang dasar pembuatan isi polis terdapat dalam Pasal 256 KUHD dan Pasal 8 Keputusan Menteri Keuangan Nomor 222/KMK.06/2003 tentang Penyelenggaran Usaha Perusahaan Asuransi dan Perusahaan Reasuransi. Dengan tidak adanya polis, perjanjian asuransi tidak menjadi batal, tetapi dalam Pasal 255 KUHD mengharuskan pembuatan perjanjian asuransi itu dalam suatu akta yang disebut polis. ${ }^{6}$

\footnotetext{
${ }^{5}$ Djoko Prakoso dan I Ketut Murtika,Hukum Asuransi Indonesia, Bina Aksara, Jakarta, 1989, hlm.1

6 Purwosutjipto, Pengertian Pokok Hukum Dagang Indonesia : Hukum Pertanggungan, Djambatan, Jakarta, 1998, hlm. 62
} 
Perjanjian asuransi akan diterbitkan dalam bentuk polis, ketika masing-masing pihak baik itu dari penanggung maupun calon tertanggung menyampaikan informasi yang benar dan jelas.

Calon tertanggung diwajibkan untuk menyampaikan seluruh fakta yang diketahuinya secara jujur tentang dirinya. Hal ini dilakukan pada saat mengadakan perjanjian, yang dalam polis asuransi ini dimasukkan ke dalam proses pengisian Surat Permintaan Asuransi Jiwa (selanjutnya disebut SPAJ). Penanggung berkewajiban menjelaskan resiko yang dijamin maupun resiko yang dikecualikan.

Keterangan secara jujur sangat penting bagi perusahaan asuransi, mengingat dari keterangan tersebut akan dapat ditentukan mengenai resiko calon tertanggung dan besaran premi yang harus dibayar tertanggung sehingga layak untuk diasuransikan. Keterangan secara jujur akan menjadi prinsip yang sangat penting dalam pelaksanaan perjanjian asuransi. Dalam asuransi istilah demikian disebut dengan Prinsip itikad baik atau Utmost Goodfaith.

Permasalahannya prinsip ini tidak selalu dimengerti oleh kedua belah pihak baik itu dari pihak penanggung maupun tertanggung.Salah satu bentuk pelanggaran terhadap prinsip itikad baik ini adalah menyembunyikan dan tidak memberikan fakta yang benar tentang kesehatan diri tertanggung. ${ }^{7}$

Tertanggung juga harus membaca polis dengan seksama, bukan hanya membaca saja melainkan perlu memahami isi polis tersebut. Misalnya kondisi apa saja yang termasuk dalam pertanggungan asuransi, penyakit tertentu yang tidak termasuk dalam penggantian asuransi, berapa besar uang pertanggungan, bagaimana bila peserta sebagai pembayar polis tidak sanggup membayar premi asuransi dan lain sebagainya.

Disini penanggung sangat berperan penting untuk menjelaskan semua isi polis kepada tertanggung.Hal ini merupakan kewajiban penanggung, apabila penanggung keberatan menjelaskan polis, tertanggung harus lebih teliti dengan melakukan pengecekan terhadap polis.

Ketentuan yang dibuat oleh perusahaan asuransi tersebut tidak boleh merugikan tertanggung sehingga dapat memperlambat proses penyelesaian atau pembayaran klaim. Ketentuan ini diatur dalam Keputusan Menteri Keuangan Nomor 222/KMK. 06/2003 tentang Penyelenggaran Usaha Perusahaan Asuransi dan Perusahaan Reasuransi, pada Pasal 25 yang menjelaskan tentang tindakan-tindakan yang dapat dikategorikan memperlambat penyelesaian atau pembayaran klaim.

\footnotetext{
7 Ketut Sendra, Klaim Asuransi: Gampang, Badan Mediasi Asuransi Indonesia dan PPM, Jakarta, 2009, hlm. 54
} 
Tertanggung yang dapat memenuhi prosedur pengajuan klaim asuransi dengan benar, maka pengajuan klaimnya akan diterima oleh penanggung serta membayar klaim sesuai dengan isi polis.

Meskipun telah jelas mengenai hak dan kewajiban dalam perjanjian asuransi namun kenyataan yang terjadi sangatlah berbeda karena ternyata penanggung tidak memenuhi kewajibannya pada saat terjadi pengajuan klaim dari tertanggung.Salah satu alasan penolakan pembayaran klaim asuransi jiwa itu terjadi karena pihak asuransi menilai cacat dan terdapat unsur ketiadaan itikad baik. Tertanggung yang ternyata men-yembunyikan fakta-fakta yang ada akan dapat merugikan dirinya sendiri.

Fakta-fakta yang diterima oleh penanggung tentu saja tidak lengkap sehingga keputusan yang diambil hanya berdasarkan pada informasi yang ada. Kerugian yang terjadi adalah kemungkinan penanggung akan menolak klaim asuransi jika terdapat keterangan yang tidak benar.

Pada Sertifikat Polis Asuransi 15.001673, merupakan produk Consumer Loan Protection hasil kerjasama antara Jasindo dengan PT. Mandiri Tunas Finance, yaitu perlindungan terhadap kredit konsumtif, berupa pinjaman yang dipergunakan untuk keperluan konsumtif, antara lain;kredit perumahan, kredit mobil, kredit motor, kartu kredit, kredit untuk membayar uang sekolah, dan lain-lain.
Pihak Jasindo pun tidak mewajibkan adanya syarat ketentuan suratmedical check up bagi nasabahnya yang ingin menerbitkan polis. Disinilah timbul permasalahan, apakah si nasabah mengetahui atau tidak penyakit yang dideritanya sebelum mengikuti asuransi dengan tidak berniat mencari keuntungan dan apakah pihak asuransi memiliki itikad baik atas perjanjian asuransi yang telah dibuatnya karena tidak mengharuskan nasabah untuk melampirkan suratmedical check up lengkap dari dokter. ${ }^{8}$

Permasalahan semakin pelik dengan adanya keterlambatan penyerahan berkas ke Jasindo oleh Mandiri Tunas Finance yang melebihi batas penyerahan berkas yaitu 60 hari, padahal pihak ahli waris telah menyerahkan berkas secara lengkap kepada Mandiri Tunas Finance dalam waktu 29 hari untuk diserahkan kepada Jasindo, namun pihak Mandiri Tunas Finance lalai dengan tidak mengirimkannya ke Jasindo.

Sertifikat Polis Asuransi 15.001673, memiliki uang pertanggungan sebesar Rp. 298.740.000 dengan Masa Pertanggungan 60 bulan (5 tahun), nasabah pada Pemegang Polis yang atas dirinya dipertanggungkan berdasarkan Polis Induk oleh Pemegang Polis. Pembayaran Premi sekaligus akan dikenakan kepada Peserta (Tertanggung) kepada Penanggung melalui Pemegang Polis.

8 Putusan Pengadilan Negeri Jakarta Selatan Nomor 352/Pdt.G/2013/PN.Jkt.Sel. 
Adanya kelalaian dari pihak PT. Mandiri Tunas Finance (MTF) selaku mitra dan kolektor berkas yang tidak menyerahkan berkas yang diserahkan ahli waris ke Jasindo selaku penanggung, sehingga berdasarkan ketentuan dari perjanjian antara MTF dan Jasindo yang juga tertuang dalam Sertifikat Asuransi Jasindo Nomor 15.001673, klaim dinyatakan nihil dengan catatan "no claim" dengan Surat Bernomor SD.0374/2053/X/2016 tertanggal 12 Oktober 2016.

\section{METODE PENELITIAN}

Penelitian ini merupakan penelitian hukum normatif yaitu penelitian yang mempunyai objek kajian tentang kaidah atau aturan. $^{9}$

Pendekatan (approach) yang digunakan di dalam penelitian ini adalah :

1. Pendekatan undang-undang (statute approach) dilakukan dengan menelaah undang-undang dan regulasi tentang perasuransian yang bersangkutan dengan isu hukum yang ditangani. ${ }^{10}$

2. Pendekatan konseptual (conceptual approach) yang dilakukan dengan menelaah pandangan-pandangan dan doktrin-doktrin yang berkembang di dalam ilmu hukum khususnya dalam hukum asuransi.

3. Pendekatan kasus (case approach) dimana peneliti nantinya akan melakukan telaah terhadap kasus-kasus yang berkaitan dengan permasalahan yang dihadapi yang telah menjadi putusan pengadilan.

\footnotetext{
${ }^{9}$ Mukti Fajar dan Yulianto Achmad, Dualisme Penelitian Hukum Normatif dan Empiris, Pustaka Pelajar, Yogyakarta, 2010, hlm. 36

10 Peter Mahmud Marzuki, Penelitian Hukum, Kencana, Surabaya, 2011, hlm. 93
}

Teknik analisa bahan hukum merupakan kegiatan dalam penelitian yang berupa melakukan kajian atau telaah terhadap hasil pengolahan data yang dibantu dengan teori-teori yang telah didapatkan sebelumnya.

\section{HASIL DAN PEMBAHASAN}

\section{Asuransi Jasindo}

Pembentukan PT Asuransi Jasa Indonesia (Persero) merupakan bagian penting dari perjalanan sejarah bangsa dan tanah air Indonesia. Sejarah tersebut bermula pada tahun 1845 ketika dilaksanakannya nasionalisasi atas NV Assurantie Maatschappij de Nederlander, sebuah perusahaan Asuransi Umum milik kolonial Belanda, dan Bloom Vander, perusahaan Asuransi Umum Inggris yang berkedudukan di Jakarta. ${ }^{11}$

\section{Proklamasi Kemerdekaan Republik} Indonesia yang dinyatakan pada 17 Agustus 1945 oleh Proklamator RI, Ir. Soekarno dan Mohammad Hatta, sekaligus meng-amanatkan pelaksanaan pemindahan kekuasaan dan kepemilikan Kerajaan Belanda kepada Pemerintah Indonesia.

Termasuk, melakukan nasionalisasi terhadap dua perusahaan tersebut dan mengubah nama ke-duanya menjadi PT. Asuransi Bendasraya yang bergerak di bidang Asuransi Umum dalam Rupiah dan PT. Umum Internasional Underwriters (UIU) yang

11 http://www.jasindo.co.id/tentang-jasindo/ detail/riwayat, di unduh pada 1 juli 2017. 
bergerak pada bidang Asuransi Umum dalam valuta asing.

Kedua perusahaan hasil tindak lanjut nasionalisasi ini bertujuan untuk memberikan manfaat yang maksimal kepada masyarakat dan memperkokoh keamanan serta perekonomian negara. $^{12}$

Dalam perjalanan bersejarahnya, melalui Keputusan Menteri Keuangan No.764/MK/IV/12/1972 tertanggal 9 Desember 1972, pemerintah Indonesia memutuskan untuk melakukan merger antara PT Asuransi Bendasraya dan PT Umum Internasional Underwriters (UIU) menjadi PT Asuransi Jasa Indonesia (Persero) sebagai sebuah Badan Usaha Milik Negara (BUMN) yang bergerak di bidang usaha Asuransi Umum. Pengesahan penggabungan tersebut selanjutnya dikukuhkan dengan Akta Notaris Mohamad Ali Nomor 1 tanggal 2 Juni 1973. ${ }^{13}$

Sebagai salah satu BUMN yang memiliki kinerja usaha gemilang di Indonesia, seluruh saham PT Asuransi Jasa Indonesia (Persero) dimiliki oleh Negara Republik Indonesia. Apalagi, perjalanan waktu telah membuktikan bahwa PT Asuransi Jasa Indonesia (Persero) atau yang dikenal dengan Asuransi Jasindo, memang memiliki pengalaman yang mumpuni, panjang dan matang di bidang Asuransi Umum bahkan sejak era kolonial. Pengalaman ini

\footnotetext{
${ }^{12}$ Ibid

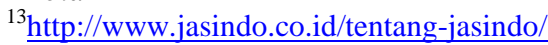
detail/perjalanan, di unduh pada 1 juli 2017.
}

memberikan nilai kepeloporan tersendiri bagi keberadaan dan pertumbuhan kinerja Asuransi Jasindo hingga saat ini, sehingga berhasil dalam meraih kepercayaan publik baik yang ada di dalam maupun di luar negeri.Pasca implementasi kebijakan nasionalisasi dan pribumi maka kemudian muncul sebuah inisiatif untuk mengoptimalkan fungsi dan peran dari kedua perusahaan nasional tersebut dalam menghadapi tantangan sekaligus mengisi era kemerdekaan Republik Indonesia.

Dalam menyuguhkan layanan profesional dan terbaiknya, Asuransi Jasindo senantiasa memegang teguh nilai-nilai budaya perusahaan yang ditanamkan yaitu Asah, Asih dan Asuh.Selain itu, Asuransi Jasa Indonesia juga berkomitmen untuk memberikan pelayanan yang prima demi memenuhi kepuasan Tertanggung.Asuransi Jasindo juga banyak mendapatkan dukungan reasuradur terkemuka dari seluruh belahan dunia, seperti Swiss Re dan Partner Re, dalam memberikan back-up reasuransi, terutama pertanggungan yang bersifat mega-risk.

Dalam menyelesaikan klaim-klaim besar, komitmen atas ketepatan dan kecepatan Asuransi Jasindo tak perlu diragukan lagi.Hal ini dibuktikan dengan penyelesaian klaimklaim besar bahkan hingga bernilai triliunan rupiah. Sebut saja misalnya, klaim Apogee Kick Motor Satelit Palapa B2 sebesar US\$ 75 juta, BDC Failure Satelit Palapa C2 senilai US\$ 31,2 juta, Battery Charging Failure Satelit Palapa C2 sebesar US\$ 36,5 juta, dan 
Loss of DB Satelit Garuda milik Aces International hingga senilai US\$ 101,5 juta.

Pengalaman dan kemampuan Asuransi Jasindo yang mengundang decak kagum ini, telah pula diakui oleh badan pemeringkat internasional yaitu Standard and Poor's untuk kategori "Claim Paying Ability" pada tahun 1997 dengan peringkat BBB. Selanjutnya, di tahun 2009, Asuransi Jasindo kembali mendapatkan pengakuan sebagai satu-satunya perusahaan Asuransi Umum nasional yang memperoleh rating dari badan pemeringkat internasional AM Best yang berbasis di Hongkong dan Amerika Serikat, untuk kategori "Financial Strength Ability" (Stable Outlook ) dengan peringkat B++ dan Issuer Credit Ability (Stable Outlook) dengan peringkat $\mathrm{BBB}$.

\section{PT. Mandiri Tunas Finance}

Pada tanggal 6 Februari 2009, PT Bank Mandiri (Persero) Tbk resmi mengakuisisi 51\% (lima puluh satu persen) saham PT Tunas Financindo Sarana. Saham yang diakuisisi oleh PT Bank Mandiri (Persero) Tbk adalah milik PT Tunas Ridean Tbk (26\%) dan milik PT Tunas Mobilindo Parama (25\%). ${ }^{14}$

PT Tunas Financindo Sarana pada awalnya didirikan pada tahun 1989 dengan nama PT Tunas Financindo Corporation, yang kemudian pada tahun 2000 berubah nama menjadi PT Tunas Financindo Sarana dengan

14 http://www.mtf.co.id/profil-kami, di unduh pada 1 juli 2017. brand "Tunas Finance". Setelah akuisisi saham oleh PT Bank Mandiri (Persero) Tbk, nama PT Tunas Financindo Sarana berubah menjadi PT Mandiri Tunas Finance dengan brand baru "Mandiri Tunas Finance".

Saat ini PT Mandiri Tunas Finance memberikan solusi pembiayaan yang mudah, inovatif dan kompetitif bagi konsumen untuk memiliki mobil (baru dan bekas), sepeda motor (khusus daerah tertentu), dan kendaraan niaga baik untuk perorangan maupun korporasi. Sejak tahun 2009 sampai saat ini PT Mandiri Tunas Finance dimiliki oleh PT Bank Mandiri (Persero) Tbk sebesar 51\% (lima puluh satu persen) dan PT Tunas Ridean Tbk sebesar 49\% (empat puluh sembilan persen). PT Bank Mandiri (Persero) Tbk merupakan bank yang memiliki asset terbesar di Indonesia dan didukung oleh lebih dari 1.300 jaringan kantor di dalam dan luar negeri dalam menyediakan solusi keuangan yang menyeluruh bagi nasabah perorangan maupun perusahaan. Sedangkan PT Tunas Ridean Tbk adalah group perusahaan penyedia solusi otomotif terpadu yang terpercaya dan disegani serta merupakan group otomotif independen terbesar di Indonesia.

PT Tunas Ridean Tbk saat ini memegang penjualan otomotif merek Toyota, Daihatsu, BMW, Peugeot dan sepeda motor Honda, juga termasuk penjualan mobil bekas dan penyewaan kendaraan.

Dengan dukungan kuat dan aliansi strategis antara PT Bank Mandiri (Persero) 
Tbk dengan PT Tunas Ridean Tbk serta hadirnya brand baru "Mandiri Tunas Finance", akan meningkatkan kemampuan PT Mandiri Tunas Finance untuk berkompetisi serta meningkatkan performa di masa yang akan datang dan menjadi perusahaan pembiayaan kendaraan bermotor yang terbaik bagi konsumen. Sampai saat ini, PT Mandiri Tunas Finance memiliki jaringan cabang di 88 titik lokasi yang tersebar di pulau Sumatera, Jawa, Kalimantan, Sulawesi, Bali dan Nusa Tenggara Barat.

Mandiri Tunas Finance melayani pembiayaan kendaraan bermotor sesuai kebutuhan anda dengan paket pembiayaan yang menarik, mudah dan cepat. Adapun produk-produk yang kami biayai adalah sebagai berikut $:^{15}$

\section{Pembiayaan Mobil}

Mandiri Tunas Finance membiayai pembelian mobil baru dengan sumber pembayaran angsuran dari total penghasilan.Hampir seluruh merek mobil telah dibiayai oleh Mandiri Tunas Finance dengan dukungan kerjasama dealer dan ATPM berbagai merek mobil.Mandiri Tunas Finance juga memiliki produk kkb (kredit kendaraan bermotor) khusus bagi nasabah bank mandiri.

2. Pembiayaan Sepeda Motor

Mandiri Tunas Finance melayani pembiayaan untuk sepeda motor premium

15 http://www.mtf.co.id/produkpembiayaan, di unduh pada 1 juli 2017. dengan harga diatas 100 juta rupiah untuk seluruh wilayah Indonesia. Untuk informasi penghitungan simulasi kredit silahkan menghubungi kantor cabang Mandiri Tunas Finance terdekat.

3. Pembiayaan Kendaraan Bermotor Skala Besar (Fleet Financing)

Untuk memenuhi kebutuhan perusahaan dalam memberikan fasilitas kendaraan bermotor bagi karyawannya, Mandiri Tunas Finance juga melayani pembiayaan Cars Ownership Program (COP) dan Motorcycles Ownership Program (MOP) bagi konsumen perusahaan/badan usaha.

Selain itu, Mandiri Tunas Finance juga memberikan fasilitas pembiayaan kendaraan niaga (commercial vehicles) dan kendaraan penumpang (passenger car) bagi perusahaan-perusahaan yang membutuhkan kendaraan operasional untuk membantu kegiatan usahanya.

4. Pembiayaan Alat-Alat Berat (Heavy Equipments)

Untuk mendukung perkembangan sektor industri dan infrastruktur, Mandiri Tunas Finance juga memberikan fasilitas pembiayaan alat-alat berat (heavy equipments) bagi konsumen perusahaan/badan hukum dengan fasilitas pembiayaan sewa guna usaha.

Bagi perusahaan/badan hukum yang ingin mengajukan pembiayaan Fleet Financing dan Heavy Equipments dapat 
menghubungi beberapa nomor telepon dibawah ini pada saat hari dan jam kerja.

Pemberian kredit/ pembiayaan kepada customer untuk kebutuhan konsumtif, dengan jaminan dokumen kepemilikan kendaraan yang dimiliki customer.Jenis kebutuhan konsumtif adalah untuk Pendidian, Pernikahan, Renovasi rumah, Travel, Kesehatan, lainnya.

\section{Polis Asuransi 15.001673}

Sertifikat Polis Asuransi 15.001673, adalah produk yang kerjasama antara Jasindo dengan Mandiri Tunas Finance, merupakan produk asuransi Consumer Loan Protection, yaitu perlindungan terhadap kredit konsumtif.

Kredit konsumtif merupakan pinjaman yang dipergunakan untuk keperluan konsumtif, antara lain;kredit perumahan, kredit mobil, kredit motor, kartu kredit, kredit untuk membayar uang sekolah, dll.

Pada saat ini banyak Bank yang gencar mengiming-imingi kredit konsumtif pada para konsumen.Pada dasarnya kredit konsumtif tidak selalu jelek, bahkan banyak yang bisa mendorong ekonomi keluarga menjadi lebih baik, asal dimanfaatkan dengan sebaikbaiknya.

Pada umumnya suku bunga kredit konsumtif lebih tinggi dibanding kredit produktif, bahkan ada yang fixed rate. Kelihatannya fixed rate memudahkan untuk menata keuangan keluarga, tinggal membayar angsuran setiap bulan dengan jumlah yang sama, tetapi kalau dihitung secara teliti sebetulnya bunganya jauh lebih tinggi. Hal ini sejalan dengan tingkat risikonya yang lebih tinggi, sehingga bunga juga dibebani lebih tinggi.

Consumer Loan Protection dengan sertifikat Polis Asuransi 15.001673 adalah produk asuransi jiwa yang memberikan jaminan pelunasan atas Jumlah Sisa Pinjaman dan/atau angsuran pinjaman bulanan nasabah sebagai Peserta (Tertanggung) pada Pemegang Polis dalam hal Peserta (Tertanggung) mengalami risiko meninggal dunia atau ketidakmampuan total sementara dan/atau ketidakmampuan total tetap. ${ }^{16}$

Sertifikat Polis Asuransi 15.001673, memiliki uang pertanggungan sebesar $\mathrm{Rp}$. 298.740.000 dengan Masa Pertanggungan 60 bulan (5 tahun), nasabah pada Pemegang Polis yang atas dirinya dipertanggungkan berdasarkan Polis Induk oleh Pemegang Polis. Pembayaran Premi sekaligus akan dikenakan kepada Peserta (Tertanggung) kepada Penanggung melalui Pemegang Polis.

Cara Pengajuan Klaim dengan mengisi Formulir Klaim dicabang Pemegang Polis yang terdekat, dalam hal ini Mandiri Tunas Finance selaku Mitra dan Kolektor Berkas serta melengkapi bukti klaim dengan jujur, benar dan lengkap. Pelaporan Klaim adalah selambat-lambatnya 30 hari kalender sejak Tertanggung meninggal dunia dan berkas

${ }^{16}$ http://www.mtf.co.id/consumerloanprotection, di unduh pada 1 juli 2017. 
dilengkapi selambat-lambatnya 60 hari kalender sejak Tertanggung meninggal dunia.

Ada kasus gagal klaim Sertifikat Polis Asuransi 15.001673, kronologisnya adalah sebagai berikut:

1. Mobil Toyota Avanza dengan nomor polisi B-1974-WOD memiliki perjanjian pembiayaan dengan PT. Mandiri Tunas Finance dengan nomor 9921502606 atas nama Suryadi Ramdan terhitung sejak 3 Januari 2016 dan telah dibayarkan sebanyak 4 bulan.

2. Sebelumnya telah terjadi kecelakaan yang menimpah mobil dengan nomor polisi B1974-WOD (STNK atas nama Istri Siti Maryam) pada 11 Juli 2016.

3. Setelah kecelakaan Suryadi Ramdan tidak mampu membayar cicilan karena mobil yang digunakan mencari nafkah masuk bengkel dan beliau sakit.

4. Suryadi Ramdan telah meninggal dunia pada 3 Agustus 2016, karena sakit gangguan pernapasan yang diderita sejak Juni 2016.

5. Setelahnya dengan surat kuasa tertanggal 5 Agustus 2016, Inawati Santini, SH., selaku salah satu penerima kuasa dan penulis thesis dikuasakan untuk:

a. Mengurus Klaim Sertifikat Asuransi Jasindo Nomor 15.001673.

b. Mengurus Klaim Asuransi PT Ace Life Assurance (Xtra Protection) Nomor 1400000034.

6. Didapat keterangan bahwa :

a. Klaim Asuransi PT Ace Life Assurance (Xtra Protection) Nomor 1400000034, telah dicairkan pada November 2016.

b. Klaim Sertifikat Asuransi Jasindo Nomor 15.001673, TIDAK CAIR, dengan alasan berkas melebihi 60 Hari diterima Jasindo, yaitu 72 hari sejak kerugian.

c. Pada kenyataannya berkas diterima oleh Mandiri Tunas Finance Pondok Gede selaku kolektor berkas Jasisdo (telah dikonfirmasi ke Jasindo bahwa berkas diserahkan ke MTF) pada tanggal 2 September 2016, (29 Hari). d. Adapun pihak MTF tidak menyerahkan berkas ke Jasindo sampai melebihi tanggal tersebut, merupakan bukan tanggung jawab ahli waris/kuasa selaku tertanggung.

Secara garis besar berdasarkan kronologis diatas, didapat kesimpulan bahwa adanya kelalaian dari pihak Mandiri Tunas Finance (MTF) selaku mitra dan kolektor berkas yang tidak menyerahkan berkas yang diserahkan ahli waris ke Jasindo selaku penanggung, sehingga berdasarkan ketentuan dari perjanjian antara MTF dan Jasindo yang juga tertuang dalam Sertifikat Asuransi Jasindo Nomor 15.001673, klaim dinyatakan nihil dengan catatan "no claim" dengan Surat Bernomor SD.0374/205-3/X/2016 yang dikeluarkan oleh Jasindo ke Mandiri Tunas Finance pada 12 Oktober 2016.

Hal ini sangat merugikan pihak ahli waris karena mereka telah menyerahkan berkas ke MTF dalam waktu 29 Hari kalender, dan MTF telah lalai dengan tidak menyerahkan berkas tersebut kepada Jasindo sampai 72 hari dalam hal berkas tertahan di MTF karena permasalahan internal yaitu adanya staf yang resign dan staf tersebut adalah penerima berkas klaim. Hasilnya klaim ditolak dan Jasindo beralasan bahwa berkas diserahkan melebihi 60 hari kalender berdasarkan ketentuan dalam sertifikat asuransi.

Pihak ahli waris kemudian meminta penerima kuasa untuk mengurus kembali pengajuan klaim tersebut langsung ke Jasindo. 
Karena ahli waris menilai adanya wanprestasi terhadap klaim yang bagi mereka telah sesuai dengan ketentuan Sertifikat Asuransi Nomor 15.001673, yaitu mereka melalui kuasa hukum telah menyerahkan berkas sesuai ketentuan bahkan sangat jauh dari batas waktu yaitu hanya dalam 29 hari kalender dari batas maksimal 60 hari kalender.

Hasil dari pertemuan antara Jasindo dengan kuasa ahli waris adalah :

1. Jasindo menolak dikatakan wanprestasi karena kenyataannya mereka menerima berkas melebihi batas waktu maksimal penerimaan berkas yaitu dalam 72 hari dari seharusnya maksimal 60 hari.

2. Prosedur pengajuan berkas telah sesuai dengan ketentuan yang berlaku pada umumnya, yaitu pelaporan dalam waktu maksimal 30 hari telah diterima oleh Jasindo, namun berkas yang terlambat diterima.

3. Ahli waris tidak tahu bahwa berkas belum diterima oleh Jasindo sampai melebihi batas waktu yang ditentukan.

4. Pihak Jasindo akan menunggu pengajuan Klaim Ex-Gratia dari Mandiri Tunas Finance kepada Jasindo.

Kemudian atas desakan penerima kuasa, MTF mengajukan Klaim XGratia ke Jasindo pada 21 Oktober 2017 dengan No Surat 568/MTF/GAB.BRS/10/2016, namun jawaban dari Jasindo berdasarkan Surat Bernomor SD.0036/205-1///2017 tertanggal 16 Januari 2017, menyatakan klaim Ex-Gratia tidak dapat diproses karena dasar penolakan adalah berkas kelengkapan dokumen diterima melebihi batas waktu maksimal penerimaan berkas.
Jika mengacu pada ketentuan Pasal 1366 KUHPerdata yang menyebutkan bahwa : "Setiap orang bertanggung jawab, bukan hanya atas kerugian yang disebabkan perbuatan-perbuatan, melainkan juga atas kerugian yang disebabkan kelalaian atau kesembronoannya."

Maka jelas terlihat bahwa Pihak Mandiri Tunas Finance bertanggung jawab atas kelalaian yang mengakibatkan gagalnya klaim asuransi.

Diperkuat dengan ketentuan Pasal 1367 KUHPerdata yang menyebutkan:

"Seseorang tidak hanya bertanggung jawab, atas kerugian yang disebabkan perbuatannya sendiri, melainkan juga atas kerugian yang disebabkan perbuatan-perbuatan orang-orang yang menjadi tanggungannya atau disebabkan barang-barang yang berada di bawah pengawasannya."

Maka Direksi PT. Mandiri Tunas Finance bertanggung jawab atas kelalaian orang-orang yang bekerja dibawah naungannya, diantaranya penerima berkas yang dikemudian hari diketahui mengundurkan diri dengan meninggalkan berkas tanpa diproses sebagaimana mestinya.

Dalam literatur-literatur perbuatan melawan hukum, kasus Lindenbaum-Cohen menjadi salah satu rujukan yang paling sering disinggung.Putusan perkara ini dirujuk ketika hendak menentukan kriteria atau cakupan perbuatan melawan hukum (onrechtmatige daad). Kasus ini diputus Hoge Raad Belanda pada 1919. 
Samuel Cohen, seorang pemilik perusahaan percetakan, berusaha mematamatai dan mencuri rahasia perusahaan saingannya milik Max Lindenbaum. Untuk memudahkan upayanya, Cohen 'menyuap' pegawai Lindenbaum agar si pegawai mau membuka rahasia dapur. ${ }^{17}$

Ketika tahu upaya tersebut, Lindenbaum menggugat Cohen membayar ganti rugi berdasarkan pasal 1401 Burgerlijk Wetboek (atau 1365 KUH Perdata). Di persidangan, Cohen berdalih apa yang dia lakukan tidak melanggar hukum karena undang-undang tidak mengaturnya.

Sempat lolos di tingkat banding, Cohen akhirnya dihukum di Hoge Raad. Majelis hakim Hoge Raad menyatakan termasuk perbuatan melawan hukum setiap perbuatan (atau tidak berbuat) yang melanggar hak subjektif orang lain, atau bertentangan dengan kewajiban hukum si pelaku, atau bertentangan dengan tata susila, kepatutan, ketelitian dan sikap hati-hati, yang seharusnya dimiliki seseorang dalam pergaulan dengan sesama warga masyarakat atau terhadap harta benda orang lain. Orang yang karena kesalahannya menyebabkan kerugian bagi orang lain wajib mengganti kerugian itu.

Putusan ini menjadi tonggak perubahan pandangan pengadilan terhadap onrechtmatige raad sebagaimana kini diatur dalam Pasal

\footnotetext{
${ }^{17}$ https://myslawlibrary.wordpress.com/2013/06/ 05/kasus-lindenbaum-cohen-1919, di unduh pada 2 juli 2017.
}

1365 KUH Perdata. Seperti dalam Polis Asuransi 15.001673, karena kelalaian pegawai PT. mandiri Tunas Finance yang tidak melakukan suatu perbuatan yang seharusnya dilakukan, maka dapat dikatakan sebagai perbuatan melawan hukum.

Sebagaimana diketahui, bunyi pasal 1365 adalah sebagai berikut:

"Tiap perbuatan melanggar hukum, yang membawa kerugian kepada seorang lain, mewajibkan orang yang karena salahnya menerbitkan kerugian itu, mengganti kerugian tersebut."

$$
\text { Sedangkan bunyi pasal } 1366
$$

KHPerdata adalah:

"Setiap orang bertanggung jawab, tidak saja untuk kerugian yang disebabkan karena perbuatannya, tetapi juga untuk kerugian yang disebabkan karena kelalaian atau kurang hatihatinya."

Istilah perbuatan (daad) dalam pasal 1365 KUHPerdata memiliki segi positif dan segi negative; segi positif yakni bilamana dengan 'perbuatan; tersebut dimaksudkan berbuat sesuatu, sedang segi negative yakni bilamana yang dimaksudkan adalah 'tidak berbuat sesuatu' (nalaten).Sedangkan dari ketentuan pasal 1366 KUHPerdata di atas dapat diketahui bahwa pengertian perbuatan (daad) dipisahkan dari pengertian "kelalaian".

Pasal 1366 menjadi pelengkap pasal 1365 KUHPerdata, dan arti "daad" (perbuatan) diperluas, yakni tidak hanya pelanggaran suatu kewajiban menurut 
undang-undang (wettelijkeplicht), melainkan juga dalam hal terjadi pelanggaran terhadap suatu hak (subjektiefrecht) yang dapat diterapkan pasal 1365 dan pasal 1366 KUHPerdata.

Jadi, hubungan antara kedua pasal tersebut adalah bahwa pasal 1365 mengenai perbuatan onrechtmatig (culpa in committendo), sedang pasal 1366 adalah mengenai perbuatan melalaikan secara onrechtmatig (culpa in ommittendo).

Sesuai dengan ketentuan dalam pasal 1365 KUH Perdata, maka suatu perbuatan melawan hukum haruslah mengandung unsur sebagai berikut :

1. Adanya suatu perbuatan

2. Perbuatan tersebut melawan hukum

3. Adanya kesalahan dari pihak pelaku

4. Adanya kerugian bagi korban

5. Adanya hubungan kausal antara perbuatan dengan kerugian ${ }^{18}$

\section{PENUTUP}

1. Keabsahan penolakan klaim asuransi jiwa yang dilakukan oleh Jasindo sesuai dengan polis asuransi dan peraturan perundangundangan yang ada, adalah sah mengingat berkas diterima melebihi batas waktu yang tertuang dalam Sertifikat Asuransi Nomor 15.001673, yaitu diterima oleh Jasindo dalam 72 hari kalender, namun dalam

${ }^{18}$ Munir Fuady, Perbuatan Melawan Hukum, Pendekatan Kontemporer, P.T.Citra Aditya Bakti, Bandung, 2002, hlm. 10 kasus ini menjadi tidak sah, mengingat ada perbuatan melawan hukum yang dilakukan oleh sub kontraktor yaitu PT. Mandiri Tunas Finance yang menerima berkas dalam waktu 29 hari kalender, yaitu tidak melebihi ketentuan yang berlaku dan kelalaian dari Mandiri Tunas Finance yang tidak menyerahkan berkas ke jasindo selaku penanggung adalah perbuatan melawan hukum yang menimbulkan kerugian bagi ahli waris tertanggung karena tidak melakukan kewajibannya mengurus berkas klaim.

2. Kesalahan Mitra (PT. Mandiri Tunas Finance) dapat diklasifikasikan sebagai Wanprestasi yang menyebabkan tidak dibayarkannya Klaim Asuransi akibat keterlambatan penyerahan berkas polis Nomor 15.001673 kepada Jasindo, namun bukan merupakan wanprestasi pembayaran klaim asuransi oleh Pihak Jasindo selaku Penanggung, melainkan wanprestasi terhadap prosedur pengajuan klaim oleh Mandiri Tunas Finance selakumitra dan pihak penerima berkas pengajuan klaim, yang telah lalai tidak mengirimkan berkas langsung kepada Jasindo.

\section{DAFTAR PUSTAKA}

\section{Buku-buku}

Abbas Salim, Dasar - Dasar Asuransi, Raja Grafindo Persada, Jakarta, 1995.

Abdulkadir Muhammad, Pokok-Pokok Hukum Pertanggungan, Citra Aditya Bakti, Bandung, 1990. 
Ali Rido, Hukum Dagang: Tentang AspekAspek Hukum Dalam Asuransi Udara, Asuransi Jiwa, dan Perkembangan Perseroan Terbatas, Remadja Karya, Bandung, 1986.

Djoko Prakoso dan I Ketut Murtika, Hukum Asuransi Indonesia, Bina Aksara, Jakarta, 1989.

Dwi Tatak Subagiyo, Analisa Hukum Atas Penolakan Klaim Asuransi Kesehatan Prespektif, Refika Aditama,Bandung, 2012.

J. Satrio, Perikatan yang Lahir karena Undang-undang, Bagian Pertama, P.T.Citra Aditya Bakti, Bandung, 1993.

Mukti Fajar dan Yulianto Achmad, Dualisme Penelitian Hukum Normatif dan Empiris, Pustaka Pelajar, Yogyakarta, 2010.

Munir Fuady, Teori Negara Hukum Modern Rehcstaat, Refika Aditama, Bandung, 2009.

Moegni Djojodirjo, Perbuatan Melawan Hukum, Tanggung Gugat (aanspraakelijkheid) untuk Kerugian, yang Disebabkan karena Perbuatan Melawan Hukum, Pradnya Paramita, Jakarta, 1982.

Ketut Sendra, Klaim Asuransi: Gampang, Badan Mediasi Asuransi Indonesia dan PPM, Jakarta, 2009.

Peter Mahmud Marzuki, Penelitian Hukum, Kencana, Surabaya, 2011.

Purwosutjipto, Pengertian Pokok Hukum Dagang Indonesia : Hukum Pertanggungan, Djambatan, Jakarta, 1998.

\section{Perundang-undangan}

Undang-Undang Dasar Negara Republik Indonesia 1945, Lembaran Negara Republik Indonesia Nomor 75 Tahun 1959.

Yurisprudensi 1919

Kitab Undang-Undang Hukum Perdata, Pasal 1365, 1366 dan 1367

Kitab Undang-Undang Hukum Dagang.
Undang-Undang Nomor 2 Tahun 1992 Tentang Usaha Perasuransian, Lembaran Negara Republik Indonesia Tahun 1992 Nomor 13, Tambahan Lembaran Negara Republik Indonesia Nomor 3467.

Undang-Undang Nomor 8 tahun 1999 tentang Perlindungan Konsumen, Lembaran Negara Republik Indonesia Tahun 1999 Nomor 42, Tambahan Lembaran Negara Republik Indonesia Nomor 3821.

Undang-Undang Nomor 21 tahun 2011 tentang Otoritas Jasa Keuangan.

Majelis Permusyawaratan Rakyat Indonesia, Panduan Pemasyarakatan UndangUndang Dasar Republik Indonesia Tahun 1945 (Sesuai dengan Urutan Bab, Pasal dan ayat), Sekertaris Jendral MPR RI, Jakarta, 2010.

Peraturan Pemerintah Nomor 81 Tahun 2008 Tentang Perubahan Ketiga Atas Peraturan Pemerintah Nomor 73 Tahun 1992 Tentang Penyelenggaraan Usaha Perasuransian, Lembaran Negara Republik Indonesia Tahun 2008 Nomor 212, Tambahan Lembaran Negara Republik Indonesia Nomor 4954.

Keputusan Menteri Keuangan Nomor 422/KMK.06/2003 Tentang Penyelenggaraan Usaha Perusahaan Asuransi dan Perusahaan Reasuransi.

Putusan Pengadilan Negeri Jakarta Selatan Nomor 352/Pdt.G/2013/PN.Jkt.Sel

Aturan Dewan Asuransi Tentang Asuransi Jiwa.

\section{Artikel \& Website}

http://www.jasindo.co.id/tentangjasindo/detail/riwayat, di unduh pada 1 juli 2017.

http://www.jasindo.co.id/tentangjasindo/detail/perjalanan, di unduh pada 1 juli 2017.

http://www.mtf.co.id/profil-kami, di unduh pada 1 juli 2017.

http://www.mtf.co.id/produkpembiayaan, di unduh pada 1 juli 2017. 